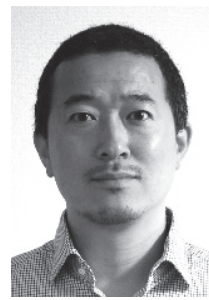

\title{
炭素繊維強化プラスチックの成形力学
}

水口 周*

\section{Process Mechanics of Carbon Fiber Reinforced Plastic}

by

\section{Shu MINAKUCHI*}

この度，複合材料部門委員会より寄稿の機会をいた だきましたので, 私の研究テーマの一つである炭素繊 維強化プラスチック複合材料の成形力学に関して, こ れまでの研究遍歴を簡単にご紹介させていただきます。

私は大学院の修士課程および博士課程においては, 高強度複合材表皮で軽量ハニカム心材を挟んだサンド イッチ構造を対象として, ハニカムの構造周期性に基 づいた損傷のモデル化や光ファイバひずみセンサを用 いた損傷検知，形状記憶合金ハニカムを用いた損傷抑 制についての研究を行っていました. ちょうどその頃, 宇宙航空研究開発機構 (JAXA) が真空圧樹脂含浸成形 法（VaRTM）による航空機複合材主翼構造実証のプロ ジェクトを実施していました。この成形法は，乾式繊 維シートを積み重ねた後に樹脂を注入し, オーブン内 で加熱して樹脂を固めるのですが, 所属研究室のメン バーがこの成形過程において複合材構造内に発生する ひずみ分布を埋め込み光ファイバで計測する目的でプ ロジェクトに参画していました，私が博士課程で対象 としていたのが，損傷発生という単一の現象であるの に対し, 成形過程は樹脂含浸, 加熱, 硬化, 冷却の各 段階で様々な現象が計測できる可能性があり，まだま だ課題の多い複合材料のものづくりに役立ちそうな データが得られていました，複合材料に埋め込むこと が出来るという光ファイバセンサの特徵を最大限生か すことのできる, 将来性のある興味深い研究テーマで あると感じていました.

その後, 2008年から大学に職を得たのですが, JAXA で実施していたプロジェクトに類似した小型のプロ ジェクトがオーストラリアの研究機関と共同で立ち上 がり, 参加させていただくことができました. 1メート ルサイズの複合材料構造をオーストラリアで成形した のち, その供試体を日本に持ち帰って荷重をかけて壊 すという一連の実証試験を実施したのですが，大量の 計測装置をオーストラリアに輸出し，複合材料の成形 から破壊までのひずみ分布の変化を連続計測すること に成功し，いわゆる，ライフサイクルモニタリングを 初めて実用的な形で実証することが出来ました。

一方で，こうした複合材成形モニタリングに取り組 むようになって気付いたこととしては, 樹脂がガラス
化した冷却過程においては大きなひずみ変化が計測さ れる一方で, 成形過程の主要な現象である, 樹脂が硬 化していく状態において計測されるひずみは $100 \mu \varepsilon 以$ 下と極めて小さいということでした．本来樹脂が硬化 すると数\%の体積収縮が起きるはずですが，他の論文 を見ても同様の結果が示されており，その頃は理由も 良く分からず, クリアなデータが得られる熱ひずみに 起因する変形や応力に関する研究に注力していました.

そうしたなか, 今度は航空機メーカと樹脂の硬化過 程について共同で研究を行う機会に恵まれました。複 合材料に応力が発生し始めるゲル化（樹脂が液体から 固体に相変化する点）のタイミングを埋め込み光ファ イバで捉えたいということでした．企業の方が持つ技 術に対する鋭い視点など大変勉強になる一方で, 難し いのではと感じながら実験を行っていましたが，ある 時に作業を担当していた学生が実験に失敗した際に, 硬化収縮によるひずみをはっきりと捉えることができ たのです．複合材料は一般に内部の空孔を抑制するた めに，真空バッグのなかで脱気された状態で成形型の 上で加熱硬化されますが, この真空バッグが破れてし まったのでした，本来であれば，ここで実験停止とな るのですが, 真空バッグが破れたのが加熱途中という こともあり最後まで実験を継続したところ, 硬化収縮 による $5000 \mu \varepsilon$ 程度のひずみが計測されました，その後 の検証の結果，これまでわずかなひずみしか計測され なかったのは，成形中に複合材料に負荷される力学拘 束が原因であることに気づきました。そこで，新たに この拘束状態を制御しながら, 複合材料の 3 次元的な 硬化収縮ひずみを計測する手法を確立し，実成形環境 下での変形挙動を明らかにすることが可能になりまし た。また，この変形挙動を再現することの出来る，成 形シミュレーションの新しい枠組みを提案・実証して きています。

こうして振り返ってみますと, 月並みではあります が, 自分とは違う経験や視点を持った方々とのコラボ レーションと失敗に恵まれることの大切さを実感しま す。ますます様々な用途に適用が広がっていくことが 期待される炭素繊維強化プラスチックですが，これか らもこうしたチャンスを逃すことなく，次世代の複合 材料技術の構築に貢献していきたいと考えています。

$\dagger \quad$ 原稿受理 令和 3 年 2 月 13 日 Received Feb. 13, 2021 C2021 The Society of Materials Science, Japan

* 正 会 員 東京大学工学系研究科 $=$ 113-8656 東京都文京区本郷 Graduate Scool of Engineering, the University of Tokyo, Bunkyo-ku, Tokyo 113-8656. 